\title{
Theoretical Basis of Fractographic Methods and Their Application in Fracture Modelling for Cr-Ni Steels
}

\author{
Veronika Klopanová ${ }^{1}$, Viktor Novák², Petra Kvasnová ${ }^{3}$, Daniel Novák ${ }^{3}$ \\ ${ }^{1}$ Matej Bel University, Faculty of Natural Sciences, Department of Mathematics, Tajovského 40, 97401 Banská Bystrica, \\ Slovakia. E-mail: veronika.klopanova@centrum.sk \\ ${ }^{2}$ Czech University of Life Sciences Prague, Faculty of Engineering, Department of Electrical Engineering and Automa- \\ tion, Kamýcká 129, 16521 Prague 6, Czech Republic. E-mail: novakviktor@tf.czu.cz \\ ${ }^{3}$ Matej Bel University, Faculty of Natural Sciences, Department of Technology, Tajovského 40, 97401 Banská Bystrica, \\ Slovakia.E-mail: petra.kvasnova@umb.sk, daniel.novak@umb.sk
}

Fractographic methods derive their knowledge from Euclidean geometry, set theory, metric theory and chaos theory. In engineering technology, the fractography is primarily used for modeling of fatigue and intergranular fractures. As such defects are not smooth due the principle of their origin, they cannot be described using ordinary mathematical tools. However, if the conditions of self-similarity are met, fractal geometry means can describe various irregular, incomprehensible, crooked or fragmented geometric shapes. Fractographic description of the fracture profile allows more accurate quantification of fractures and it also enables identifying possible causes of their initiation. This study contains several examples of specific cases of $\mathrm{Cr}$-Ni steel failures and a basic explanation of their fractographic description.

Keywords: Optical microscopy, Fractography, Cr-Ni steel, Micro fracture, Macro fracture

\section{References}

[1] ZELINKA, I., VČELǍ̌, F., ČANDÍK, M. (2006). Fraktální geometrie - principy a aplikace. Praha: Nakladatelství BEN - technická literatura, 2006, pp. 80-88.

[2] VORÁČOVÁ, Š. et al. (2012). Atlas geometrie. Praha: Academia, 2012, pp. 228-229.

[3] Dendrity (mangánové povlaky v tvare rastlín) na hornine z lokality Dargov [online], 2017 [cit. 2017-04-15]. Available from: https://presov.korzar.sme.sk/c/7548554/krajske-muzeum-v-presove-predstavilo-novu-expoziciuneziva-priroda.html>

[4] L-systems Turtle Graphics Renderer [online], 2017 [cit. 2017-04-15]. Available from $<$ http://www.kevs3d.co.uk/dev/lsystems/>

[5] LAUSCHMANN, H., BEDNǍ̌ÍK, P., SEKEREŠOVÁ, Z., BENEŠ, M. (2008). Fractal image vector swith applications in fractography, Image Anal Stereols 27, pp. 63-71.

[6] PAGGI, M., PLEKHOF, O. (2014). On the dependency of the parameters of fatigue crack growth from the fractal dimension of rough crack profiles. Proceedings of the Institution of Mechanical Engineers, Part C: Journal of Mechanical Engineering Science 228(12), pp. 2059-2067.

[7] HOTAR, A., HOTAR, V. (2015). Fractal Geometry Used for Evaluation of Corrosion Resistance of Fe-14Al-6Cr Wt. \% against Molten Glass. Manufacturing Technology, Vol. 15, No. 4, pp. 534-541.

[8] Quantitative Fractography, Fractography. (1987), Vol. 12, ASM, s.356-398.

[9] HRIVŇÁK, I. (1986). Elektrónová mikroskopia ocelí. Bratislava: Veda, 284 pages.

[10] MÖSER, M. (1982).Elektronenmikroskopische Fraktographie, Elektronen-mikroskopie in der Festkörperphysik, Hrsg. H. Bethgeund J. Heydenreich, Berlin: VEB Deutscher Verlag der Wissenschaften, 1982, pp. 341-358.

[11] MAHJANI, M. G., MOSHREFI, R., SHARIFI-VIAND, A., TAHERZAD, A., JAFARIAN, M., HASANLOU, F., HOSSEINI, M. (2016). Surface investigation by electrochemical methods and application of chaos theory and fractal geometry. Chaos, Solitons and Fractals 91, pp. 598-603.

[12] NOVOTNÝ, J., HONZÍKOVÁ, J., PILOUS, V., STRÁNSKÝ, K. (2016). Verification for the causes of the degradation of welded joints in power plant. Manufacturing Technology, Vol. 16, No. 5, pp. 1106-1110.

[13] LU, Ch. (2007) Some notes on the study of fractals in fracture, Proceding 5th Australian Congress on Applied Mechanics, Brisbane, 2007, pp. 234-239.

[14] KOBAYASHI, S., KOBAYASHI, R., WATANABE, T. (2016). Control of grain boundary connectivity based on fractal analysis for improvement of intergranular corrosion resistance in SUS316L austenitic stainless steel, Acta Materialia 102, pp. 397-405. 
[15] BROWN, C. A., HYDE, J. M., MONTGOMERY, J. (2014). Microscopy reveals effect sofmicro-electric discharge machining on stainless steel. Laser Focus World 50(7), pp. 49-52.

[16] AHMADIAN, Z., DANAEE, I., GOLOZAR, M. A. (2014). Effect of surface treatment on corrosion resistance of 304 stainless steel implants in Tyrodesolution. Archives of Metallurgy and Materials, 59(1), pp. 25-30.

[17] LIN, N., GUO, J., XIE, F., ZHANG, H., TANG, B. (2014). Comparison of surface fractal dimensions of chromizing coating and P110 steel for corrosion resistance estimation. Applied Surface Science, 311, pp. 330-338.

\section{Paper number: M2017169}

Copyright $\odot$ 2017. Published by Manufacturing Technology. All rights reserved. 